\title{
Anteseden Dari Process Orientation Serta Dampaknya Terhadap Financial Performance dan Patient Satisfaction
}

\author{
Yusak, Ferdi Antonio \\ Fakultas Kedokteran Universitas Pelita Harapan, Jakarta, Indonesia \\ Yusaksuhardi@gmail.com
}

\begin{abstract}
Abstrak
Rumah sakit di Indonesia wajib mengutamakan kepentingan pasien dan menjaga kualitas mutu pelayanannya. Rumah sakit swasta yang semakin meningkat jumlahnya setiap tahun harus terus berinovasi untuk meningkatkan financial performance perusahaan dan patient satisfaction. Penelitian sebelumnya mengungkapkan bahwa pendekatan proses kerja dapat mempengaruhi persepsi karyawan untuk memiliki fokus pelayanan dan memberikan dukungan finansial secara organisasi untuk menciptakan competitive advantage. Tujuan penelitian ini yaitu melihat pengaruh process orientation terhadap financial performance dan patient satisfaction yang dimediasi oleh variabel operational efficiency, workforce condition, dan clinical quality pada Rumah Sakit Swasta XYZ di Indonesia. Penelitian ini menggunakan metode kuantitatif yang bersifat correlational antar variabel dengan pendekatan maksimal likehood partial least square. Penelitian dilakukan terhadap 167 karyawan RS swasta XYZ dengan pengumpulan data menggunakan kuesioner dengan skala likert pada bulan Maret 2021. Analisis data pada penelitian ini menggunakan metode PLS-SEM. Hasil penelitian ini menunjukan adanya pengaruh positif yang kuat antara process orientation melalui variabel operational efficiency (T-Statistik $=0,668$ ), workforce condition ( $\mathrm{T}$-Statistik $=0,726$ ) dan clinical quality (T-Statistik $=0,580$ ) terhadap patient satisfaction dan finacial performance. Penelitian ini juga menemukan tidak ada pengaruh yang signifikan pada workforce condition terhadap operational efficiency ( $\mathrm{T}$-Statistik=0,087). Model hasil penelitian ini menunjukan predictive accuracy sedang $\left(R^{2}=0,502\right)$ sehingga perlu dikembangkan lebih lanjut pada penelitian berikutnya.
\end{abstract}

Kata kunci: Financial Performance, Process Orientation

\begin{abstract}
Hospitals in Indonesia must prioritize patient's interests and maintain the quality of their services. Private hospitals which are increasing every year must innovate continuously to improve the company's financial performance and patient satisfaction. Previous research shows the work process approach can affect employee perceptions to have service focus on patient satisfaction and provides organizational support. The purpose of this study is to examine the effect of Process Orientation on Financial Performance and Patient Satisfaction which is supported by Operational Efficiency, Workforce Condition, and Clinical Quality factors at XYZ private hospital in Indonesia. This research is a quantitative study with a cross-sectional study design and is correlational between variables with a maximum likelihood approach, Partial Least Squares. The sample of this study was 167 respondents with data collection using a questionnaire with a Likert scale. This study used the PLS-SEM method to analyze data. Finding from this study shows a significant positive effect between process orientation through operational efficiency (T-Statistic $=0,668$ ), workforce condition ( $T$ Statistic $=0,726)$, and clinical quality variable $(T$-Statistic $=0,580)$, to patient satisfaction and financial performance. This study researcher found workforce condition to not have a significant effect on operational efficiency (T-Statistic $=0,087$ ). The result model in this study show moderate predictive accuracy $\left(R^{2}=0,502\right)$ thus more developments are needed to improve this study further.
\end{abstract}

http://ejournal.urindo.ac.id/index.php/jukmas

Article History :

Submitted 30 Juli 2021, Accepted 23 Oktober 2021, Published 31 Oktober 2021 
Keywords: Financial Performance, Process Orientation

\section{PENDAHULUAN}

Pada Tahun 2020 terjadi pandemi global infeksi coronavirus (SARS-CoV-2) yang dikenal dengan Covid-19. Pandemi Covid-19 mempunyai dampak langsung terhadap seluruh pelayanan kesehatan termasuk salah satunya adalah rumah sakit. Pandemi ini mendorong manajemen rumah sakit untuk menghadapi tantangan baru dimana rumah sakit harus terus memberikan pelayanan kesehatan yang berkualitas bagi pasien serta harus mengelola anggarannya secara efisien meskipun adanya pengeluaran tambahan untuk melaksanakan protokol kesehatan. Dalam menghadapi pandemi ini manajemen rumah sakit juga perlu memperhatikan karyawan dan tenaga kesehatan yang bekerja didalamnya karena memiliki risiko tinggi untuk terinfeksi virus Covid19. ${ }^{(1)}$

Negara Indonesia menerapkan sistem pembangunan kesehatan nasional dimana rumah sakit memiliki peranan penting dalam sistem ini. Seluruh rumah sakit termasuk rumah sakit swasta dapat berkontribusi dalam sistem pembangunan kesehatan nasional dengan mendirikan dan mengelola rumah sakit secara mandiri. (2) Kementerian Kesehatan Republik Indonesia sebagai regulator di bidang kesehatan menjamin kualitas pelayanan kesehatan melalui akreditasi rumah sakit. Seluruh rumah sakit di Indonesia wajib mengutamakan kepentingan pasien dan menjaga kualitas mutu pelayanannya.
Berdasarkan data kementerian kesehatan, rumah sakit yang beroperasional di Indonesia dimiliki oleh berbagai pihak seperti swasta, perusahaan, organisasi, pemerintah, dan BUMN.

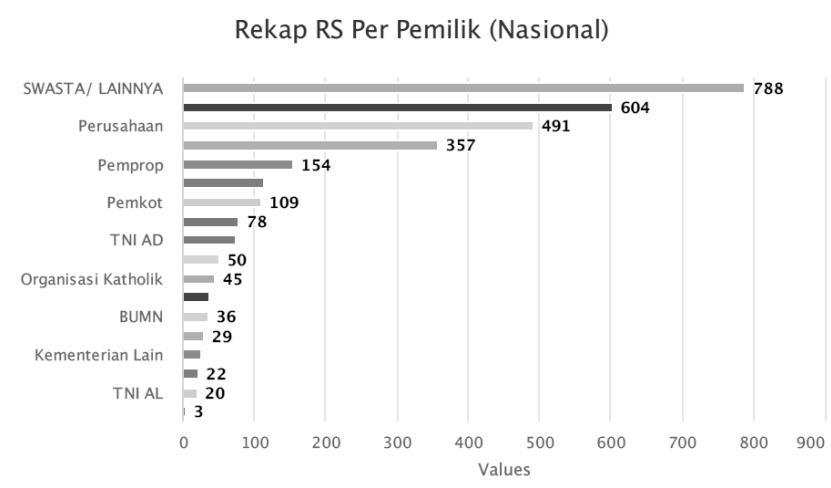

Gambar 1. Jumlah Kepemilikan RS di Indonesia

Sumber: (Kementerian Kesehatan Republik Indonesia, 2021)

Hingga tahun 2021 pertumbuhan rumah sakit milik swasta lebih banyak dibandingkan rumah sakit lainnya, dari grafik di atas dapat diketahui jumlah rumah sakit milik swasta mencapai 788 rumah sakit sementara rumah sakit milik pemerintah maupun kabupaten sebanyak 604 rumah sakit. ${ }^{(3)}$ Persaingan industri rumah sakit semakin ketat dengan terus bertambahnya jumlah rumah sakit swasta dan rumah sakit baru lainnya, sehingga rumah sakit swasta harus meningkatkan kemampuan kompetitifnya dalam bersaing khususnya dalam kondisi pandemi untuk menjaga pertumbuhan bisnisnya. 
Saat ini salah satu rumah sakit milik swasta yang sedang berkembang adalah grup rumah sakit XYZ yang berdiri sejak tahun 2010. Grup rumah sakit ini memiliki 9 rumah sakit yang tersebar di Pulau Jawa dengan sebagian besar rumah sakit berada dalam tipe C dan D. Grup rumah sakit ini berfokus dalam memberikan pelayanan kesehatan pada pasien umum, termasuk pasien peserta BPJS. Sehingga grup rumah sakit ini harus melakukan proses efisiensi harus dilakukan dengan baik karena harus berfokus pada kendali mutu dan kendali biaya. Seluruh rumah sakit yang berada dalam naungan grup rumah sakit XYZ memiliki perbedaan lokasi, sumber daya serta kinerja sehingga memerlukan suatu pendekatan manajemen untuk memastikan tercapainya efisiensi dan kualitas pelayanan yang sama satu sama lain. Grup rumah sakit XYZ memiliki tujuan yang sama pada seluruh rumah sakit naungannya, yaitu menciptakan kepuasan pasien yang maksimal serta kinerja finansial yang baik. Selain itu grup rumah sakit XYZ merupakan suatu perusahaan berkembang baru yang terbuka pada inovasi dan telah mencoba melakukan pendekatan process orientation, sehingga hal ini menarik untuk diteliti lebih lanjut. Pada 9 rumah sakit yang dinaungi oleh grup rumah sakit XYZ dipilih 3 rumah sayang yang memiliki standar yang mirip yaitu rumah sakit tipe $C$, memiliki tempat tidur di atas 100 , serta rumah sakit dengan pendapatan terbesar dalam grup rumah sakit XYZ. Pemilihan ketiga rumah sakit ini dilakukan agar mendapatkan data yang comparable dan dapat memberikan informasi manajemen yang relevan bagi rumah sakit yang sejenis.

Berdasarkan data internal rumah sakit terdapat beberapa fenomena business gap yang menunjukkan bahwa tingkat kepuasan pasien yang masih dibawah target. Tingkat kepuasan pasien RS Swasta XYZ pada tahun 2018 memiliki rata-rata 93,6\% dan pada tahun 2019 yaitu 94\% dimana target yang harus dicapai minimal yaitu 95\%. Studi pendahuluan menunjukkan sumber daya manusia pada RS Swasta XYZ memiliki persepsi bahwa pendekatan proses kerja di rumah sakit perlu ditingkatkan dan masih rendahnya persepsi karyawan mengenai pelayanan rumah sakit yang berfokus pada pasien.

Pendekatan proses kerja dapat mempengaruhi persepsi karyawan bahwa rumah sakit memiliki fokus utama pada pelayanan yang mengutamakan kepuasan pasien dan telah memberikan dukungan secara organisasi. ${ }^{(4)}$

Salah satu pendekatan manajemen untuk menjalankan dan mengembangkan rumah sakit adalah process orientation. ${ }^{(6)(7)}$ Konsep orientasi proses (process orientation) yaitu perusahaan berfokus pada proses bisnis yang berada dalam perusahaannya untuk menciptakan daya saing atau competitive advantage. ${ }^{(8)(9)}$ Konsep utama dari orientasi proses yaitu memposisikan proses dalam perusahaan dengan berfokus pada konsumen, dalam hal ini yaitu kepuasan pasien. (10) (11) Pendekatan ini merupakan pendekatan manajemen yang relevan dengan kebutuhan 
manajemen rumah sakit khususnya rumah sakit swasta yang sedang menghadapi tantangan pandemi Covid-19.

Penelitian sebelumnya yang dilakukan oleh Cleven tahun 2016 memiliki konsep process orientation sebagai variabel independen yang mempunyai pengaruh terhadap kinerja organisasi yang ditinjau dari variabel financial performance dan patient satisfaction sebagai variabel dependen. ${ }^{(12)}$ Pada penelitian tersebut pengaruh process orientation didukung oleh proses internal organisasi dari variabel operational efficiency, workforce condition, dan clinical quality pada rumah sakit. Hasil dari penelitian tersebut memperlihatkan adanya pengaruh dari process orientation pada daya saing dari proses internal rumah sakit dan memiliki dampak pada persepsi karyawan terhadap kinerja rumah sakitnya. Persepsi yang positif ini akan mempengaruhi moral, semangat kerja karyawan, meningkatkan continuous improvement di rumah sakit. (4) (9) Serta meningkatkan keterlibatan karyawan dalam program efisiensi yang dilakukan manajemen.$^{(10)}$ Penelitian tersebut dilakukan pada rumah sakit di Eropa dengan sistem pembiayaan kesehatan yang lebih baik dan derajat kesehatan masyarakat lebih tinggi, sehingga model penelitian tersebut perlu diuji pada populasi yang berbeda. Maka dibentuklah penelitian ini dengan tujuan untuk menguji pengaruh process orientation terhadap financial performance dan patient satisfaction melalui operational efficiency, workforce condition dan clinical quality pada karyawan dan tenaga kesehatan yang bekerja di rumah sakit swasta milik grup rumah sakit XYZ di Jakarta.

\section{METODE}

Penelitian ini merupakan penelitian kuantitatif dengan desain penelitian crosssectional study yang bersifat correlational antar variabel dengan pendekatan maksimal likehood yaitu partial least square. ${ }^{(13)}$ Variabel pada penelitian ini, yaitu process orientation sebagai variabel independent, patient satisfaction dan financial performance sebagai variabel dependent, serta variabel mediasi yang terdiri dari workforce condition, operational efficiency dan clinical quality.

Populasi penelitian ini adalah seluruh karyawan yang bekerja pada 3 rumah sakit milik grup rumah sakit swasta XYZ di Jakarta dan sekitarnya pada tahun 2021. Metode pengambilan sampel pada penelitian ini menggunakan metode probability sampling dengan teknik simple random sampling yang didapatkan 167 responden. Data diambil pada bulan Maret 2021 melalui survei secara daring pada responden dengan instrumen kuesioner yang disusun berdasarkan variabel penelitian. Skala pengukuran menggunakan skala likert dengan poin 1 = Sangat tidak setuju, poin $2=$ tidak setuju, poin $3=$ netral, poin $4=$ setuju dan poin 5 = sangat setuju.

Data yang dikumpulkan dianalisis dengan pendekatan analisis multivariate dengan metode partial least square - structural equation 
modelling (PLS-SEM) yang berbasiskan variance. Penggunaan metode PLS-SEM pada penelitian ini dikarenakan sifat analisa metode ini adalah pengembangan teori dalam penelitian exploratory sehingga sesuai dengan tujuan penelitian ini, yaitu untuk kemampuan explanation dan predictive model penelitian. Pada tahap pengujian hipotesis penelitian dilakukan uji signifikansi hubungan antar variabel dengan menggunakan perbandingan nilai T-tabel dengan T-statistic yang dihasilkan melalui bootstrapping. (15) Dalam penelitian ini digunakan tingkat signifikansi $\alpha=$ 0,05 , dengan degree of freedom digolongkan infinity maka nilai T-tabel untuk hipotesis onetailed adalah 1,645. (17) Setelah pengujian hipotesis dilakukan analisis jalur untuk melihat kemampuan mediasi dari variabel mediasi dalam penelitian ini serta untuk melihat nilai specific indirect dan signifikansinya. (18) Selanjutnya dengan melihat nilai koefisien determinasi atau $R^{2}$. Nilai ini untuk menentukan kemampuan explanatory dan prediksi model yang diajukan untuk diuji empiris. ${ }^{(13)}$ Tahap selanjutnya yaitu menilai $Q^{2}$ untuk menilai kemampuan prediksi model serta dipertajam dengan nilai $Q^{2}$ _predict untuk memvalidasi kemampuan prediksi. ${ }^{(16)}$

\section{HASIL DAN PEMBAHASAN}

Dari 167 responden yang memenuhi kriteria penelitian memiliki gambaran profil responden sebagai berikut.
Tabel 1. Profil Demigrafi Responden

\begin{tabular}{|c|c|c|c|}
\hline \multicolumn{2}{|c|}{ Variabel } & $n$ & $\%$ \\
\hline \multirow{5}{*}{$\begin{array}{c}\text { Usia } \\
\text { (Tahun) }\end{array}$} & $18-29$ & 45 & $27 \%$ \\
\hline & $30-39$ & 60 & $36 \%$ \\
\hline & $40-49$ & 33 & $20 \%$ \\
\hline & $50-59$ & 21 & $13 \%$ \\
\hline & $>60$ & 8 & $5 \%$ \\
\hline \multicolumn{2}{|c|}{ Total } & 167 & $100 \%$ \\
\hline \multirow{2}{*}{$\begin{array}{c}\text { Jenis } \\
\text { Kelamin }\end{array}$} & Wanita & 118 & $71 \%$ \\
\hline & Pria & 49 & $29 \%$ \\
\hline \multicolumn{2}{|c|}{ Total } & 167 & $100 \%$ \\
\hline \multirow{5}{*}{$\begin{array}{l}\text { Pendidi- } \\
\text { kan } \\
\text { Terakhir }\end{array}$} & $\begin{array}{c}\text { SMA/sed } \\
\text { erajad }\end{array}$ & 21 & $13 \%$ \\
\hline & $\begin{array}{c}\text { D3/seder } \\
\text { ajad }\end{array}$ & 73 & $44 \%$ \\
\hline & $\begin{array}{c}\text { S1/seder } \\
\text { ajad }\end{array}$ & 51 & $31 \%$ \\
\hline & S2/S3 & 14 & $8 \%$ \\
\hline & $\begin{array}{c}\text { Dokter } \\
\text { Spesialis }\end{array}$ & 8 & $5 \%$ \\
\hline \multicolumn{2}{|c|}{ Total } & 167 & $100 \%$ \\
\hline
\end{tabular}

Berdasarkan Tabel 1 di atas responden penelitian ini didominasi oleh responden yang berusia $<40$ tahun $(63 \%)$, jenis kelamin wanita (71\%) dan pendidikan terakhir diploma III (44\%). Sehingga dapat disimpulkan bahwa Sebagian besar responden memiliki latar belakang pendidikan yang tinggi, maka dianggap mampu untuk memahami pertanyaan-pertanyaan dalam kuesioner yang bersifat teknis dan konseptual dengan baik.

Tabel 2. Profil Pekerjaan Responden

\begin{tabular}{cccc}
\hline & Variabel & $\mathbf{n}$ & $\%$ \\
\hline \multirow{3}{*}{$\begin{array}{c}\text { Masa } \\
\text { Kerja } \\
\text { (Tahun) }\end{array}$} & $<1$ & 11 & $6 \%$ \\
\cline { 2 - 4 } & $1-3$ & 26 & $16 \%$ \\
\cline { 2 - 4 } & $3-5$ & 57 & $34 \%$ \\
\cline { 2 - 4 } & \multicolumn{1}{c}{$5-10$} & 53 & $32 \%$ \\
\hline \multirow{2}{*}{ Jabatan } & Total & 20 & $12 \%$ \\
\hline & Staf medis & 75 & $45 \%$
\end{tabular}




\begin{tabular}{ccc}
\hline $\begin{array}{c}\text { Staf non } \\
\text { medis }\end{array}$ & 31 & $19 \%$ \\
$\begin{array}{c}\text { Supervisor } \\
\text { /sederajad }\end{array}$ & 23 & $14 \%$ \\
\hline Manager & 11 & $7 \%$ \\
\hline Direktur & 3 & $2 \%$ \\
\hline $\begin{array}{c}\text { Dokter } \\
\text { fungsional }\end{array}$ & 21 & $13 \%$ \\
\hline Lainnya & 3 & $2 \%$ \\
\hline Total & 167 & $100 \%$ \\
\hline
\end{tabular}

Berdasarkan Tabel 2 diketahui bahwa Sebagian besar responden memiliki masa kerja $<5$ tahun (56\%) dan memiliki jabatan sebagai staf medis (45\%) atau sebagai perawat, sehingga data yang diberikan berasal dari responden yang berhubungan langsung dengan perawatan pasien. Hal ini diperlukan karena berhubungan dengan penilaian pada variabel clinical quality dan operational efficiency. Ditinjau dari latar belakang posisi karyawan dan masa kerjanya yangcukup bervariasi, dapat disimpulkan bahwa responden sudah dapat menggambarkan kondisi rumah sakit, demikian juga sudah dapat memahami sistem dan pola kerja yang berhubungan dengan variabel-variabel penelitian.

Data yang sudah dikumpulkan diolah dalam tabel seperti pada Tabel 3 di bawah. Setiap variabel diberikan penulisan singkat dengan definisi $\mathrm{PO}=$ Process Orientation, OE = Operational Efficiency, $\mathrm{WC}=$ Workforce Condition, $\mathrm{CQ}=$ Clinical Quality, $\mathrm{FP}=$ Financial Performance, dan PS= Patient satisfaction.

Tabel 3. Hasil Uji Hipotesis

\begin{tabular}{|c|c|c|c|c|c|}
\hline $\begin{array}{l}\text { Hip } \\
\text { otes } \\
\text { is }\end{array}$ & Path & $\begin{array}{c}\text { Stand } \\
\text { ardiz } \\
\text { ed }\end{array}$ & $\begin{array}{c}\mathrm{T} \\
\text { Stati } \\
\text { stics }\end{array}$ & $\begin{array}{c}\text { Signi } \\
\text { fikas } \\
\text { i }\end{array}$ & Hasil \\
\hline
\end{tabular}

\begin{tabular}{|c|c|c|c|c|c|}
\hline $\mathrm{H} 1$ & $\begin{array}{l}P O-> \\
O E\end{array}$ & 0,668 & $\begin{array}{c}9,22 \\
0\end{array}$ & $\begin{array}{l}\text { Signi } \\
\text { fikan }\end{array}$ & $\begin{array}{c}\text { Hipotesis } \\
\text { Didukun } \\
\text { g }\end{array}$ \\
\hline $\mathrm{H} 2$ & $\begin{array}{l}P O-> \\
W C\end{array}$ & 0,726 & 18,689 & $\begin{array}{l}\text { Signi } \\
\text { fikan }\end{array}$ & $\begin{array}{c}\text { Hipotesis } \\
\text { Didukun } \\
\mathrm{g}\end{array}$ \\
\hline $\mathrm{H} 3$ & $\begin{array}{l}P O-> \\
C Q\end{array}$ & 0,580 & $\begin{array}{c}8,33 \\
5\end{array}$ & $\begin{array}{l}\text { Signi } \\
\text { fikan }\end{array}$ & $\begin{array}{c}\text { Hipotesis } \\
\text { Didukun } \\
\mathrm{g} \\
\end{array}$ \\
\hline $\mathrm{H} 4$ & $\begin{array}{l}W C \rightarrow> \\
O E\end{array}$ & 0,008 & $\begin{array}{c}0,08 \\
7\end{array}$ & $\begin{array}{l}\text { Tida } \\
k \\
\text { Signi } \\
\text { fikan }\end{array}$ & $\begin{array}{c}\text { Hipotesis } \\
\text { Tidak } \\
\text { Didukung }\end{array}$ \\
\hline $\mathrm{H} 5$ & $\begin{array}{l}W C-> \\
C Q\end{array}$ & 0,165 & $\begin{array}{c}2,23 \\
3\end{array}$ & $\begin{array}{l}\text { Signi } \\
\text { fikan }\end{array}$ & $\begin{array}{c}\text { Hipotesis } \\
\text { Didukun } \\
\mathrm{g} \\
\end{array}$ \\
\hline $\mathrm{H} 6$ & $\begin{array}{ll}O E & -> \\
F P & \end{array}$ & 0,414 & $\begin{array}{c}5,25 \\
2\end{array}$ & $\begin{array}{l}\text { Signi } \\
\text { fikan }\end{array}$ & $\begin{array}{c}\text { Hipotesis } \\
\text { Didukun } \\
\text { g }\end{array}$ \\
\hline $\mathrm{H} 7$ & $\begin{array}{ll}O E & -> \\
P S & \end{array}$ & 0,395 & $\begin{array}{c}9,38 \\
5\end{array}$ & $\begin{array}{l}\text { Signi } \\
\text { fikan }\end{array}$ & $\begin{array}{c}\text { Hipotesis } \\
\text { Didukun } \\
\mathrm{g}\end{array}$ \\
\hline $\mathrm{H} 8$ & $\begin{array}{l}W C-> \\
F P\end{array}$ & 0,259 & $\begin{array}{c}2,81 \\
0\end{array}$ & $\begin{array}{l}\text { Signi } \\
\text { fikan }\end{array}$ & $\begin{array}{c}\text { Hipotesis } \\
\text { Didukun } \\
\mathrm{g}\end{array}$ \\
\hline $\mathrm{H} 9$ & $\begin{array}{l}W C-> \\
P S\end{array}$ & 0,353 & $\begin{array}{c}6,91 \\
2\end{array}$ & $\begin{array}{l}\text { Signi } \\
\text { fikan }\end{array}$ & $\begin{array}{c}\text { Hipotesis } \\
\text { Didukun } \\
\mathrm{g}\end{array}$ \\
\hline $\mathrm{H} 10$ & $\begin{array}{l}C Q-> \\
F P\end{array}$ & 0,195 & $\begin{array}{c}2,28 \\
7\end{array}$ & $\begin{array}{l}\text { Signi } \\
\text { fikan }\end{array}$ & $\begin{array}{c}\text { Hipotesis } \\
\text { Didukun } \\
\mathrm{g}\end{array}$ \\
\hline $\mathrm{H} 11$ & $\begin{array}{l}C Q-> \\
P S\end{array}$ & 0,267 & $\begin{array}{c}4,94 \\
1\end{array}$ & $\begin{array}{l}\text { Signi } \\
\text { fikan }\end{array}$ & $\begin{array}{c}\text { Hipotesis } \\
\text { Didukun } \\
\text { g }\end{array}$ \\
\hline
\end{tabular}

Pada Tabel 3 di atas dapat ditemukan bahwa dari 11 hipotesis yang ada dalam model penelitian, terdapat 10 hipotesis yang signifikan dengan nilai koefisien yang positif sesuai dengan arah pada hipotesis yang diajukan. Terdapat satu hipotesis yang tidak mempunyai pengaruh signifikan yaitu pengaruh workforce condition terhadap operational efficiency (T-statistik = 
0,087 ) dengan arah positif yang kecil (Koefisien = 0,008), sehingga hipotesis tidak didukung. Temuan ini tidak sejalan dengan penelitian terdahulu ${ }^{(11)}$ hal ini dapat disebabkan karena ketika pengambilan sampel penelitian karyawan rumah sakit berada dalam kondisi pandemi Covid-19 yang penuh ketidak pastian (uncertaincty). Selain itu selama pandemi jumlah pasien yang berobat berkurang karena risiko terpapar Covid-19 di fasilitas Kesehatan besar.

Tabel 4. Hasil Uji Specific Indirect Effect

\begin{tabular}{|c|c|c|c|}
\hline Path & $\begin{array}{c}\text { Standardized } \\
\text { Coefficient }\end{array}$ & $\begin{array}{c}\mathbf{T} \\
\text { Statistic } \\
\mathrm{S} \\
\end{array}$ & Signifikansi \\
\hline $\begin{array}{l}\mathrm{PO}-> \\
\mathrm{CQ}-> \\
\mathrm{FP}\end{array}$ & 0,113 & 2,069 & Signifikan \\
\hline $\begin{array}{l}P O-> \\
W C-> \\
C Q-> \\
F P\end{array}$ & 0,023 & 1,593 & $\begin{array}{c}\text { Tidak } \\
\text { Signifikan }\end{array}$ \\
\hline $\begin{array}{l}\text { PO -> } \\
\text { OE -> } \\
\text { FP }\end{array}$ & 0,276 & 4,431 & Signifikan \\
\hline $\begin{array}{l}P O-> \\
W C-> \\
\text { OE -> } \\
\text { FP }\end{array}$ & 0,002 & 0,086 & $\begin{array}{c}\text { Tidak } \\
\text { Signifikan }\end{array}$ \\
\hline $\begin{array}{l}P O-> \\
W C-> \\
F P\end{array}$ & 0,188 & 2,763 & Signifikan \\
\hline $\begin{array}{l}\mathrm{PO}-> \\
C Q-> \\
P S\end{array}$ & 0,155 & 3,901 & Signifikan \\
\hline $\begin{array}{l}\mathrm{PO}-> \\
W C-> \\
C Q-> \\
P S\end{array}$ & 0,032 & 2,024 & Signifikan \\
\hline $\begin{array}{l}\text { PO -> } \\
\text { OE -> } \\
\text { PS }\end{array}$ & 0,264 & 6,375 & Signifikan \\
\hline $\begin{array}{l}P O-> \\
W C-> \\
O E->\end{array}$ & 0,002 & 0,086 & Signifikan \\
\hline
\end{tabular}

\begin{tabular}{llll}
\hline PS & & & \\
\hline PO $->$ & & & \\
WC $\rightarrow$ & 0,256 & 6,528 & Signifikan \\
PS & & & \\
\hline
\end{tabular}

Selanjutnya dilakukan analisis jalur yang ada dalam model penelitian untuk melakukan penilaian kemampuan dari masing-masing variabel mediasi dalam memediasi pengaruh dari variable independent. ${ }^{(17)}$ Berdasarkan Tabel 4, diketahui jalur yang memiliki pengaruh paling kuat dari process orientation menuju variabel financial performance adalah melalui jalur operational efficiency (Koefisien=0,276) serta jalur dari process orientation menuju variabel patient satisfaction juga melalui operational efficiency (Koefisien = 0,264).

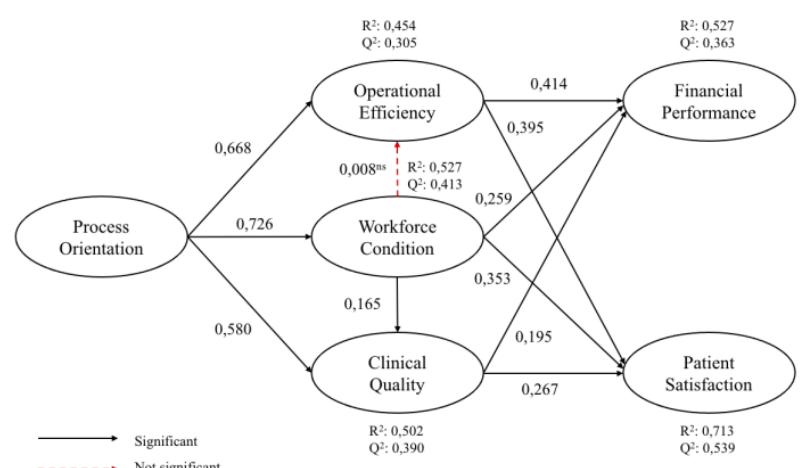

Gambar 2. Model Hasil (Empirical Model)

Pada model hasil penelitian ini process orientation mempunyai pengaruh paling paling kuat terhadap workforce condition $(0,726)$. Hal ini sejalan dengan penelitian terdahulu (11) dan memperkuat teori organisasi bahwa dalam meningkatkan persepsi karyawan terhadap workforce condition di rumah sakit perlu dilakukan pendekatan organisasi dengan process orientation yang optimal. (4) (18) Variabel operational efficiency memiliki pengaruh paling 
kuat terhadap variabel patient satisfaction $(0,414)$ dan financial performance $(0,395)$. Hal ini tidak sejalan dengan penelitian terdahulu yang menyatakan bahwa pengaruh langsung paling kuat yaitu berasal dari workforce condition. ${ }^{(11)}$ Namun temuan penelitian ini sejalan dengan penelitian Ko et al yang menemukan pengaruh kuat dari operational efficiency terhadap patient satisfaction. ${ }^{(18)}$ Adanya perbedaan penelitian ini dengan penelitian terdahulu dapat disebabkan karena tempat penelitian ini merupakan rumah sakit yang melayani pasien BPJS Kesehatan yang diatur pemerintah, sehingga rumah sakit harus mampu mengelola budget sesuai sistem asuransi yang berlaku di Indonesia. Temuan penelitian ini dapat mendukung temuan penelitian terdahulu (18), bahwa operational efficiency adalah faktor competitive advantage yang penting dimiliki dan harus dikembangkan oleh organisasi healthcare atau pelayanan kesehatan untuk menang bersaing. Hasil penelitian ini menemukan bahwa variabel patient satisfaction merupakan variabel yang mempunyai predictive accuracy sedang $\left(R^{2}=0,502\right)$ dengan large predictive relevance $\left(Q^{2}\right.$ $=0,390)$. Sehingga dapat dikatakan penelitian ini memiliki kualitas model explanatory dan prediksi yang memadai.

Hasil penelitian ini yang menunjukkan adanya pengaruh langsung paling kuat terhadap financial performance dan patient satisfaction berasal dari operational efficiency yang menunjukkan bahwa variabel operational efficiency merupakan fokus dan hal yang perlu diperhatikan dalam mengelola rumah sakit khususnya rumah sakit swasta dengan menggunakan pendekatan process orientation. Process orientation terbukti memiliki pengaruh signifikan pada ketiga variabel mediasi, kemudian ketiga variabel mediasi tersebut terbukti memiliki direct effect pada kedua variabel kinerja rumah sakit. Hal tersebut dapat mempengaruhi komitmen, moral dan semangat kerja karyawan serta meningkatkan partisipasi karyawan dalam aktivitas continuous improvement. ${ }^{(12)}$ (9) Lebih lanjut juga ditunjukkan bahwa hal-hal tersebut dapat mengurangitingkat turnover karyawan. Ketiga variabel mediasi ini dapat menunjukkan adanya tahapan-tahapan yang dapat dimonitor dan dievaluasi oleh manajemen rumah sakit secara terus menerus karena berhubungan dengan kinerja organisasi secara keseluruhan.

Hasil penelitian ini menunjukan pentingnya operational efficiency untuk diterapkan pada manajemen rumah sakit terutama di era pandemi Covid-19. Manajemen rumah sakit perlu menanamkan budaya kerja berdasarkan proses secara berulang dan sedini mungkin seperti melalui program orientasi karyawan baru yang didalamnya terdapat materi mengenai manfaat process orientation dalam pelayanan kesehatan sehingga pendekatan kerja melalui process orientation dapat menjadi bagian dari budaya perusahaan. Manajemen perlu memastikan adanya pelatihan secara berkala untuk karyawan dalam konteks continuous improvement terutama 
pada masa pandemi Covid-19. Pendekatan kerja berbasis process orientation memiliki dampak besar pada persepsi karyawan terhadap rumah sakit mengenai kondisi kerja yang kondusif untuk karyawannya, sehingga komunikasi manajemen dengan karyawan harus terus diperhatikan termasuk perlunya komunikasi horizontal yang baik antar karyawan dalam departemen yang berbeda. Manajemen dapat mengupayakan acara-acara atau program yang dapat mendorong kerjasama antar karyawan dalam rumah sakit. Temuan penelitian menunjukkan persepsi karyawan terhadap penanggung jawab yang berperan dalam sistem pengambilan keputusan dalam lingkungan pekerjaannya di rumah sakit XYZ masih kurang dan perlu untuk ditingkatkan. Hal ini dapat dilakukan dengan membuat struktur organisasi dan penjelasan kewenangan yang lebih baik serta adanya penanggung jawab resmi yang tertulis dalam SOP di rumah sakit. Pemberdayaan supervisor atau koordinator sebagai pengawas juga perlu ditingkatkan seperti dengan menyusun key performance indicator (KPI) yang sesuai dengan tanggung jawab dan kewenangannya di rumah sakit. Temuan penelitian menunjukan persepsi karyawan rumah sakit terhadap operational efficiency memiliki dampak yang signifikan terhadap persepsi tentang kinerja perusahaan karena itu diperlukan sistem kerja yang berfokus pada operational efficiency. Manajemen rumah sakit swasta perlu memastikan efisiensi proses dalam pelayanan tidak mengurangi kualitas pelayanan bagi pasien. Bagi rumah sakit yang memberikan pelayanan dengan penjaminan BPJS kesehatan maka perlu dipastikan bahwa efisiensi proses pelayanan yang berjalan sesuai dengan sistem pendanaan berdasarkan tarif INA-CBG, maka penting bagi rumah sakit untuk mempunyai case manager yang handal untuk memastikan sistem asuransi tersebut sejalan dengan sistem pelayanan rumah sakit. Pada sisi lain proses pelayanan kesehatan yang efisien dapat memastikan tarif rumah sakit yang lebih terjangkau dan mengurangi beban pasien dimana pertimbangan tersebut akan mendorong pasien untuk datang berobat. Namun dalam situasi pandemi Covid-19, manajemen rumah sakit harus tetap memperhatikan patient and employee safety. Evaluasi berkelanjutan harus terus dilakukan untuk memastikan tidak ada waste di lini pelayanan pasien dan pendukungnya. Pada penelitian ini ditemukan beberapa keterbatasan yang diharapkan dapat menjadi masukan bagi atau rekomendasi bagi penelitian selanjutnya. Pertama, responden penelitian ini terbatas dari rumah sakit swasta tipe C dimana tingkat kompleksitas pelayanan dan jumlah unit pelayanan medis dan penunjang medis yang lebih sedikit dibanding rumah sakit tipe $B$ dengan karyawan yang lebih banyak dan uraian jabatan yang lebih beragam. Kedua, responden penelitian diambil pada seluruh jenjang karyawan di rumah sakit, termasuk pada jenjang staf dengan masa kerja yang relatif pendek dibawah 3 tahun. Hal tersebut dapat memungkinkan terjadinya bias dalam mengisi kuesioner, karena pemahaman yang masih terbatas. Pada penelitian berikutnya disarankan 
untuk menggunakan responden yang telah bekerja minimal 3 tahun dan berada pada posisi minimal supervisor atau koordinator dengan pemahaman yang lebih baik agar dapat memberikan gambaran yang lebih mendekati kondisi aktual rumah sakit. Ketiga, pengumpulan data dilakukan pada saat pandemi Covid-19, dimana kebijakan baru dan langkah taktis berubah secara berkala. Hal-hal seperti perubahan alokasi anggaran seperti pengadaan alat pelindung diri, prosedur desinfeksi tambahan di ruangan dan fasilitas pelayanan, serta pemeriksaan swab rutin untuk karyawan dapat mempengaruhi persepsi karyawan terhadap workforce condition dan operational efficiency.

\section{KESIMPULAN}

Penelitian ini merupakan penelitian kuantitatif yang dilakukan kepada 167 karyawan RS Swasta XYZ yang didominasi oleh staf medis wanita dengan masa kerja $<5$ tahun. Penelitian ini menunjukkan bahwa terdapat hubungan yang signifikan pada pengaruh process orientation terhadap financial performance dan patient satisfaction melalui operational efficiency, workforce condition dan clinical quality pada karyawan dan tenaga kesehatan yang bekerja di rumah sakit swasta XYZ. Namun penelitian ini juga menemukan bahwa workforce condition tidak terbukti secara signifikan mempunyai pengaruh pada operational efficiency. Model hasil penelitian ini dapat memprediksikan dengan adekuat variabel patient satisfaction, sehingga model penelitian ini dapat disarankan untuk direplikasi dan diuji pada populasi yang berbeda.

Temuan penelitian ini dapat memberikan masukan bahwa manajemen rumah sakit perlu melihat karyawannya sebagai aset strategis yang dapat memberikan keunggulan kompetitif bagi rumah sakit melalui pelayanan yang unggul dan manfaat process orientation dapat ditanamkan kepada karyawan sedini mungkin sehingga menjadi budaya kerja yang meningkatkan kinerja organisasi dan meningkatkan competitive advantage. Penelitian ini memiliki keterbatasan yang dapat menjadi rekomendasi bagi penelitian selanjutnya. Pengambilan data penelitian ini dilakukan pada saat periode pandemi Covid-19, dimana rumah sakit melakukan kebijakan baru dan mengambil langkah taktis untuk menghadapi situasi ini. Hal tersebut dapat mempengaruhi persepsi karyawan terhadap workforce condition dan operational efficiency. Untuk itu perlu adanya pengembangan indikator pada variabel yang terdampak pandemi. Dengan demikian variabelvariabel tersebut dapat lebih relevan dengan kondisi yang dihadapi rumah sakit saat ini.

\section{DAFTAR PUSTAKA:}

1. Labrague L, De Los Santos JAA. Fear of Covid-19, Psychological Distress, Work Satisfaction and Turnover Intention Among Frontline Nurses. Wiley. 2020.

2. Kemenkes, inventor; Peraturan Menteri Kesehatan Republik Indonesia No 3 Tahun 
2020.. 2020.

3. Kemenkes. SIRS Online. [Online].; 2021. Available from: https://sirs.kemkes.go.id/fo/home.

4. Pires ML. Working Conditions and Organizational Support Influence on Satisfaction and Performance. European Journal of Applied Business and Management. 2018 Apr; 3: 162-186.

5. Teece D, Pisano G, Shuen A. Dynamic Capabilities and Strategic Management. Strategic Management Journal. 1997; 18(7): 509-533.

6. Gemmel P, Vandaelea D, Tambeur W. Hospital Process Orientation (HPO): The Development of a Measurement Tool. Total Quality Management \& Business Excellence. 2008; 19(12): 1207-1217.

7. Kohlbacher M. The Effects of Process Orientation: a Literatur Review. Business Process Management Journal. 2010; 16(1): 135-152.

8. Porter ME. Competitive Advatage: Creating \& Sustaining Superior Performance: The Free Press; 1985.

9. Van Assen MF. The Moderating Effect of Management Behavior for Lean and Process Improvement. Operation Management Res. 2018; 11: 1-13.

10. Kohlbacher M, Gruenwald S. Process

Orientation: Conceptualization and Measurement. Business Process

Management Journal. 2011; 17(2): 267-283.
11. McCormack K. Business Process Orientation: Do You Have It?. Quality Progress. 2001; 34(1): 51-60.

12. Cleven A, Mettler T, Rohner P, Winter R. Healthcare Quality Innovation and Performance Through Process Orientation: Evidence From General Hospitals in Switzerland. Technological Forecasting and Social Change. 2016; 11: 386-395.

13. Hair JF, Hult GTM, Ringle CM, Sarstedt. A Primer on Partial Least Squares Structural Equation Modeling (PLS-SEM). 2nd ed.: Sage Publications; 2017.

14. Hensler J, Ringle CM, Sarstedt M. A New Criterion for Assessing Discriminant Validity in Variance-based Structural Equation Modeling. Journal Academy of Marketing Science. 2015; 43(1): 115-135.

15. Ringle CM, Sven W, Becker JM. SmartPLS GmbG, Boenningstedt. Hournal od Service Science and Management. 2015; 10(3).

16. Shmueli G, Sarstedt M, Hair JF, Cheah JH, Ting H. Preditive Model Assessment in PLSSEM: Guidelines for Using PLSpredict. Europian Journal of Marketing. 2018.

17. Chin WW. The Partial Least Squares Approach to Structural Equation Modeling. Modern Methods for Business Research. 1998; 295(2): 295-336.

18. Nitzl C, Roldan JL, Cepeda G. Mediation Analysis in Partial Least Squares Path Modeling: Helping Researchers Discuss 
Jurnal Untuk Masyarakat Sehat (JUKMAS)

More Sophisticated Models. Industrial

Management \& Data System. 2016.

19. Sarstedt, Marko, Ringle CM, Hair JF. Partial Least Squares Structural Equation Modeling.

26th ed.: Handbook of Market Research;

2017.

20. Ko DG, Mai F, San Z, Zhang D. Operational

Efficiency and Patient-Centered Health

Care: A View From Online Physician

Reviews. Journal of Operations

Management. 2019; 65(4): 353-379. 